\title{
PENGABDIAN MASYARAKAT MELALUI SOSIALISASI PROTOKOL KESEHATAN MENGHADAPI PANDEMI COVID-19
}

\author{
Dwi Susilowati*, Defi Widiyasari, Salvita Ayu Mayangsari, M. Alfi Ridhansyah, Fandi, \\ Shinta Pramesti Suryo Putri, Natasha Angeline, M. Sholahuddin Fawwas, Neva Lis \\ Safitri, Tiara Mursyidah, M. Rojabi Thoyalisy \\ Fakultas Pertanian, Universitas Islam Malang \\ *Korespondensi email: dwi_s@unisma.ac.id
}

\begin{abstract}
ABSTRAK
Wabah Corona virus (COVID-19) saat ini sudah menyebar pada seluruh dunia dan tidak terkecuali di Indonesi. Kondisi seperti ini tidak pernah sebelumnya terjadi sehingga belum ada vaksin dan obatnya. Oleh karena itu salah satu cara untuk menghadapinya agar pandemi tersebut tidak cepat meluas yaitu menerapakan protokol kesehatan yaitu memakai masker, jaga jarak dan sering cuci tangan. Akan tetapi belum semua masyarakat terbiasa dengan protokol kesehatan, sehingga menjadi penting untuk disosialisasikan agar semua masyarakat dapat menerapkan protokol kesehatan. Pengabdian masyarakat melalui sosialisasi protokol kesehatan dalam menghadapi pandemi Covid-19 dilakukan diberbagai daerah di wilayah Jawa Timur yaitu Kabupaten Lumajang, Kota Batu, Kabupaten Gresik, Kabupaten Tulungagung, Kabupaten Ngawi, Kabupaten Trenggalek, Kota Malang. Kegiatan sosialisasi dilakukan dengan tahapan membuat dan mendesain poster-poster protokol kesehatan menghadapi pandemi Covid-19, melatih dan membagikan masker untuk dipakai kegiatan sehari-hari dan melatih pemanfaatan lahan pekarangan untuk penyediaan pangan keluarga. Hasil yang dapat disampaikan dari kegiatan sosialisasi protokol kesehatan dalam menghadapi pandemi adalah masyarakat dalam menerapkan protokol kesehatan menghadapi pandemi covid-19 meningkat, masyarakat dapat membuat masker dan mulai memanfaatkan pekarangan untuk menyediakan pangan keluarga.
\end{abstract}

Kata Kunci: covid-19; protokol kesehatan; pekarangan; pangan keluarga.

\section{PENDAHULUAN}

Penyebaran wabah Corona virus (COVID-19) sangat luar biasa, dan tidak pernah sebelumnya terjadi pandemi sebesar ini di dunia (Mona, 2020). Sejak pertama kali COVID19 terkonfirmasi di Cina pada akhir Desember 2019. Tren jumlah pasien positif terinfeksi COVID-19 terus meningkat (Yuliana, 2020). Data per tanggal 25 Maret 2020, penyebaran COVID-19 telah menginfeksi sekitar 445.753 orang di 189 negara dengan jumlah kematian mencapai 19.767 orang, dan 112.037 orang diantaranya sembuh. Di Indonesia telah terkonfirmasi positif COVID-19 pada periode yang sama sebanyak 790 orang dengan jumlah kematian mencapai 58 orang dan 31 orang dinyatakan sembuh (Siagian, 2020; Susilo et al., 2020).

Pemerintah Indonesia bergerak cepatuntuk mengambil kebijakan pasca World Health Organization (WHO) mengumumkan bahwa wabah Corona Virus Disease 2019 (COVID-19) telah menjadi pandemi dunia. Artinya wabah penyakit ini telah terjadi pada geografis yang luas atau menyebar secara global (199 negara). Kondisi tersebut mendesak pemerintah meningkatkan upaya pembatasan dan pencegahan (Utomo, 2020). 
Telah ditetapkan kebijakan baru oleh pemerintah yaitu kebijakan New Normal yang mana hal ini didasari oleh adanya pandemi Covid 19 yang menyerang Indonesia (Muhyiddin, 2020). Sehingga masyarakat harus menyesuaikan keadaan dengan kebijakan baru ini. Yang artinya kehidupan telah berubah dan tata cara hidup juga berubah tidak sama lagi seperti masa sebelumnya. Kebijakan yang ditetapkan pemerintah juga didasari oleh faktor lainnya yang mana kebijakan itu dibuat untuk kebaikan masyarakatnya (Habibi, 2020; Budianta, 2020).

Kebijakan tersebut akan membatasi dan berdampak pada beberapa kegiatan yang akan dilaksanakan dengan sejumlah aturan. Aturan yang ditetapkan tidak sembarang aturan yang mana dilakukan melalui tahapan yang ketat. Setiap kegiatan yang dilakukan harus dipastikan sesuai dengan protokol kesehatan yang baru (Rizal, 2020). Sehingga hal ini juga mempengaruhi kegaitan masyarakatnya. Dalam kebijakan tersebut belu tentu semua bisa langsung menerapkan sehingga kegiatan yang dilakukan harus berdaptasi dengan kebijakan New Normal ini.

Sebenarnya kebijakan ini dibuat karena kasus covid 19 di Indonseia masih mengalami peningkatan. Sehingga terbentuklah kebijakan ini agar pertumbuhan ekonomi tetap terdorong (Alkatiri, Nadiah, \& Nasution, 2020). Sebenarnya kebijakan ini memungkinkan masyarakat melakukan kegiataannya dengan mengindahkan protokol kesehatan seperti contoh nya selalu memakai masker saat keluar.

Namun kebijakan New Normal di Indonesia ini belum berjalan dengan lancar. Yaitu seperti kurva epidemi tidak menurun. Hal ini karena masyarakat beranggapan pandemi covid 19 ini telah terkendali sehingga kebijakan pemerintah ini membangun rasa aman yang semu, hal ini dikarenakan jumlah kasus yang terus meningkat sehingga Indonesia menjadi bagian teratas kasus covid di dunia. Karena anggapan tersebut masyarakat menjadi menyepelekan dengan tidak mengindahkan protokol kesehatan yang telah ditetapkan (Taufik, 2020).

Selain itu alasan lainnya karena kebijakan ini cenderung mengabaikan realitas bahwa masyarakat memiliki kebutuhan dan kerentanan yang beragam semasa pandemi. Karena protokol ini masih memiliki strategi yaitu pembatasan fisik dan penggunaan APD. Bagi masyarakat yang mampu strategi tersebut tidak menjadi masalah, tetapi bagi masyarakat yang kurnag mampu maka akan mengalami kesulitan untuk bekerja dari rumah atau menyediakan APD secara mandiri. Sehingga starategi ini cenderung menempatkan individu sebagai pengemban tnggungjawab. Sedangkan untuk meningkatkan jaminan kesehatan dan sosial dilakukan secara berkelanjutan.

\section{METODE}

Tulisan ini merupakan hasil pengamatan secara langsung diberbagai daerah yang ada di Jawa Timur yaitu Lumajang, Tulungagung, Ngawi, Gresik, Batu, Trenggalek dan Malang. sedangkan studi literatur untuk mengetahui berbagai kondisi danperkembangan penyebaran COVID-19 yang saat ini terjadi di Indonesia saat New Normal. Pengamatan dari beberapa daerah pada provinsi Jawa Timur. dilakukan dengan bagi-bagi alat pelindung diri seperti masker, handsanitaizer dan poster untuk mengamati bagaimana kondisi masyarakat tersebut.

Metode studi literatur, yaitu dengan cara mengamati perubahan perilaku masyarakat, karena adanya perubahan sosial ekonomi yang disebabkan masyarakat itusendiri (internal) dan perubahan karenapengaruh dari luar (external). Analisis data dilakukan dengan teknik deskripsi, sehingga dimungkinkan untuk dapat memberikan gambaran keadaan masyarakat saat new normal. 
Dalam beberapa daerah di Provinsi Jawa Timur terutama di daerah pedesaan masih kekurangan informasi tentang New Normal ini. Hal ini seperti dapat dilihat di pedesaan memang sebagian besar telah memakai masker tetapi masker yang digunakan tetap atau sudah tidak layak pakai. Hal ini karena masayarakat berpendapat telah mematuhi aturan dan kekurangan masker. Keadaan ini didasari pembiayaan pada kehidupan mereka juga sudah terbebani.

\section{HASIL DAN PEMBAHASAN}

Angka kematian akibat virus corona di Indonesia tertinggi di Asia setelah Cina, meninggal 181 orang, persentase kematian 9,11\%, jumlah kasus virus corona 1.986 kasus, sembuh 134 orang.3 Sampai tanggal 5 April 2020 terkonfirmasi Covid-19 berjumlah 2.273 orang, sembuh 164 orang dan meninggal 198 orang. Mengingat wabah Covid-19 merupakan masalah global melanda di belahan Negara-Negara di duniatermasuk Indonesia.

Wabah virus Corona berkembang begitu cepat berdampak negatif terhadap aktivitas sosial masyarakat dan ekonomi masyarakat, bangsa dan negara. Warga yang paling terdampak virus Corona warga yang bekerja di sektor informal, seperti ojek online, sopir angkot, home industri, pekerja harian, nelayan, dan sektor UMKM dan non UMKM, seperti pusat perbelanjaan mal, supermarket, pusat jajanan makanan dan minuman, omsetnya menurun dengan drastis karena pembeli sepi. Pelaku usaha banyak menutup usahanya karena daya beli masyarakat turun.

Van Doorn seorang sosiologi Belanda menyatakan, hukum adalah skema yang dibuat untuk menata (perilaku) manusia, tetapi manusia itu sendiri cenderung jatuh pada skema yang ditentukan. Hal ini disebabkan faktor pengalaman, pendidikan, tradisi dan lainnya yang mempengaruhi dan membentuk perilakunya. Oleh karena itu, Indonesia menghadapi tekanan kuat untuk segera membuka perekonomiandemi merangsang pertumbuhan ekonomi, mengurangi tingkat pengangguran dan mencegah peningkatan angka kemiskinan. Kebijakan normal baru memungkinkan masyarakat mulai bekerja kembali, bersekolah membuka pusat perbelanjaan dengan mengindahkan protokol kesehatan. Namun kebijakan new normal di Indonesia masih memiliki kelemahan-kelemahan. Salah satunya kebijakan ini masih memihak ke dalam masyarakat menengah ke atas.

Dari hasil pengamatan dan studi literatur beberapa daerah di Jawa Timur yaituLumajang, Tulungagung, Ngawi, Gresik, Batu, Trenggalek dan Malangmasih belum menerapkan protokol kesehatan yang telah di sosialisasikan dalam hidup new normal. Masyarakat yang menerapkan protkol kesehatan hanya di pusat kota saja tetapi masyarakat yang tinggal di pedesaan belum menerapkannya. Masyarakat desa banyak yang tdak memakai masker saat beraktivitas, yang memakai masker hanya beberapa saja itu pun masker yang dimiliki tidak banyak. Anggapan masyarakat desa terhadap adanya virus corona sudah hilang sehingga mereka sudah tidak lagi menerapkan protkol kesehatan dan mereka juga sering bepergian tanpa memperhatikan jaga jarak.

Hukum sebagai kaidah sosial, tidak berarti bahwa pergaulan manusia dalam masyarakat diatur oleh hukum, tetapi harus dipedomani dengan moral manusia, agama, kaidah susila, kesopanan, dan kebiasaan dan kaidah lainnya harus terjalin dengan erat sat sama lainnya. Melawan Covid-19 dapat dilakukan dengan menggunakan hukum sebagai kaidah sosial yang bukan hanya tugas dan tanggung jawab pemerintah, tetapi merupakan tanggung jawab bersama, baik tenaga kesehatan, pihak swasta, anggota dan tokoh masyarakat dan pemuka agama, media massa dan aparat penegak hukum serta seluruh anggota masyarakat melawan Covid-19.

Peran anggota masyarakat sangat dibutuhkan sebagai upaya untuk melawan covid 19, memutuskan mata rantai penyebaran virus Corona dengan melakukan sosial distancing 
(menjaga jarak), lockdown, karantina wilayah, tetap menjaga kesehatan dan kebersihan lingkungan, penyediaan Alat Pelindung Diri (APD). Hal yang paling sederhana dan paling efektif menekan dan memutus mata rantai penyebaran Covid -19 adalah untuk tidak keluar untuk tetap di rumah saja, dan menjaga jarak, jika berada di tempat umum atau keramaian, menggunakan masker serta sering untuk mencuci tangan dan cukup istirahat agar kekebalan tubuh tetap terjaga dengan baik.

Orang yang kekebalan tubuhnya bagus tidak akan terkena Covid-19, tetapi walaupun tidak terkena Covid-19 namun berpotensi sebagai penular. Oleh sebab itu masing-masing warga hendaknya menjaga diri untuk tidak terkena Covid-19, dengan meningkatkan kedisiplinan, patuh, taat terhadap peraturan dan himbauan yang telah ditetapkan oleh baik pemerintah pusat maupun pemerintah daerah. Pencegahan wabah Covid-19 adalah tugas kita bersama pemerintah (pusat dan daerah), tiap anggota masyarakat, organisasi masyarakat, pihak swasta dan aparat penegak hukum. Dengan adanya pembagian masker, handsanitaizer dan penyebaran poster masyarakat desa bisa terbantu baik ekonomi maupun sosial serta mendapatkan edukasi tentang tata cara hidup new normal agar tetap waspada dan terhindar dari serangan covid-19.

\section{KESIMPULAN}

Berdasarkan uraian diatas disimpulkan bahwa upaya untuk menstabilkan perekonomian warga Indonesia melakukan kebijakan new normal dimana masyarakat harus bisa menempatkna diri untuk tetap bisa berjuang di masa pandemi seprti ini. Memutus mata rantaipenyebaran Covid-19 merupakan tanggung jawab bersama pemerintah, masyarakat, pihak swasta, lembaga keagamaan, tokoh agama, aparat penegak hukum, media sosial dan media elektronik untuk bersinergis saling bantu membantu, bahu membahu, salingmengingatkan satu sama lain, bekerja keras melawan Covid-19.

Dampak wabah Covid-19 hampir di semua sektor kehidupan masyarakat antara lain bidang sosial, ekonomi, pariwisata, tempat hiburan, transportasi umum, pusat perbelanjaan mengalami penurunan secara drastis seiring mewabahnya penyebaran Covid19. Sedang upaya pencegahan penyebaran Covid-19 merupakan tugas bersama, Pemerintah dan anggota masyarakat.

Setiap warga masyarakat agar mendisiplinkan diri mematuhi peraturan, kebijakan dan himbauan pemerintah rangka memutus mata rantai penyebaran Covid- 19. Pemerintah, dan warga masyarakat bahu membahu, saling membantu, mendukung, mengingatkan satu sama lain bersama melawan Covid-19. Pemerintahagar belajar dengan Negara lain yang telah berhasil menangani wabah Covid-19, seperti kedisiplinan warga Wuhan menaati peraturan pemerintahnya.

\section{DAFTAR RUJUKAN}

Alkatiri, A. B. M., Nadiah, Z., \& Nasution, A. N. S. (2020). Opini Publik Terhadap Penerapan New Normal Di Media Sosial Twitter. CoverAge: Journal of Strategic Communication, 11(1), 19-26. Retrieved from http://journal.univpancasila.ac.id/index.php/coverage/article/view/1728

Budianta, A. (2020). "Kehidupan Baru”, Adaptasi Hadapi Pandemi. Kementerian Keuangan Republik Indonesia.

Retrieved from https://www.djkn.kemenkeu.go.id/artikel/baca/13107/Kehidupan-Baru-AdaptasiHadapi-Pandemi.html

Habibi, A. (2020). Normal Baru Pasca Covid-19. Journal.Uinjkt.Ac.Id, 4(1), 197-202. Retrieved from http://journal.uinjkt.ac.id/index.php/adalah/article/view/15809

Mona, N. (2020). Konsep Isolasi Dalam Jaringan Sosial Untuk Meminimalisasi Efek 
Contagious (Kasus Penyebaran Virus Corona Di Indonesia). Jurnal Sosial Humaniora Terapan, 2(2), 117-125. https://doi.org/10.7454/jsht.v2i2.86

Muhyiddin. (2020). Covid-19, New Normal, dan Perencanaan Pembangunan di Indonesia. Jurnal Perencanaan Pembangunan: The Indonesian Journal of Development Planning, 4(2), 240-252. https://doi.org/10.36574/jpp.v4i2.118

Rizal, J. G. (2020). Tentang New Normal Life, Hidup Berdamai dengan Covid-19 seperti Diungkapkan Presiden Jokowi. Retrieved from https://www.kompas.com/tren/read/2020/05/09/201453065/tentang-newnormal-life-hidup-berdamai-dengan-covid-19-seperti-diungkapkan?page=all

Siagian, T. H. (2020). Mencari Kelompok Beresiko Tinggi Terinfeksi Virus Corona Dengan Discourse Network Analysis. Jurnal Kebijakan Kesehatan Indonesia: JKKI, 9(2), 98106. https://doi.org/10.22146/jkki.55475

Susilo, A., Rumende, C. M., Pitoyo, C. W., Santoso, W. D., Yulianti, M., Herikurniawan, H., ... Yunihastuti, E. (2020). Coronavirus Disease 2019: Tinjauan Literatur Terkini. Jurnal Penyakit Dalam Indonesia, 7(1), 45-67. https://doi.org/10.7454/jpdi.v7i1.415

Taufik, H. W. (2020). Birokrasi Baru Untuk New Normal: Tinjauan Model Perubahan Birokrasi Dalam Pelayanan Publik di Era Covid-19. Dialogue Jurnal Ilmu Administrasi Publik, 2(1), 1-18. Retrieved from https://ejournal2.undip.ac.id/index.php/dialogue/article/view/8182

Utomo, A. P. (2020). WHO Umumkan Virus Corona sebagai Pandemi Global. Kompos.Com. Retrieved from https://www.kompas.com/global/read/2020/03/12/001124570/who-umumkanvirus-corona-sebagai-pandemi-global?page=all

Yuliana. (2020). Corona virus diseases (Covid -19); Sebuah tinjauan literatur. Wellness and Healthy Magazine, 2(1), 187-192. https://doi.org/10.2307/j.ctvzxxb18.12 